\title{
Disasters in Kashmir: Impact \& Response
}

\author{
Dr. Ruheela Hassan \\ Assistant Professor, Department of Journalism and Mass Communication, Islamic University of Science and \\ Technology (IUST), Awantipora, Kashmir
}

\begin{abstract}
The state of Jammu and Kashmir has a unique geographical personality. It is well endowed in renewable natural resources. Its mighty rivers, evergreen forest, snow covered peaks, invigorating climate and humane population are unparallel in the world. The valley of Kashmir is famous for its beauty and natural scenery throughout the world. Its high snow-clad mountains, scenic spots, beautiful valleys, rivers with ice-cold water, attractive lakes and springs and ever-green fields, dense forests and beautiful health resorts, enhance its grandeur and are a source of great attraction for tourists.

The State is distinct from rest of the states in terms of its topography, climate, economy, social setting and because of its strategic location. Besides all this, the State is a multi-hazard prone region of the country. It has a long history of natural hazards like floods, famines, fires, earthquakes, high velocity winds and landslides. The earthquakes have a very high frequency of occurrence in whole of the State, incessant floods are recurrently occurring in the valley, high velocity windstorms occur in Ladakh and the valley while as landslides I avalanches is a widespread phenomenon in the hilly areas of the State.

Despite being so vulnerable and prone to disasters, there is no literature available on the subject. No serious research has been conducted in this direction so far. The purpose of this paper is to provide an overview of natural disaster scenario, to understand the historicity of disasters in Kashmir with their frequency, document the disaster mitigation mechanism in Jammu and Kashmir and to suggest measures for reducing vulnerability to hazards.
\end{abstract}

Keywords: Disasters, Kashmir, Earthquakes, Mitigation, vulnerability.

\section{Introduction}

The state of Jammu and Kashmir has a unique geographical personality. It is well endowed in renewable natural resources. Its mighty rivers, evergreen forest, snow covered peaks, invigorating climate and humane population are unparallel in the world. The valley of Kashmir is famous for its beauty and natural scenery throughout the world. Its high snow-clad mountains, scenic spots, beautiful valleys, rivers with ice-cold water, attractive lakes and springs and ever-green fields, dense forests and beautiful health resorts, enhance its grandeur and are a source of great attraction for tourists.

The State is distinct from rest of the states in terms of its topography, climate, economy, social setting and last but not least a strategic location. Besides all this, the State is a multi-hazard prone region of the country. It has a long history of natural hazards like floods, famines, fires, earthquakes, high velocity winds and landslides. The earthquakes have a very high frequency of occurrence in whole of the State, incessant floods are recurrently occurring in the valley, high velocity windstorms occur in Ladakh and the valley while as landslides / avalanches is a widespread phenomenon in the hilly areas of the State.

Despite being so vulnerable and prone to disasters, there is no literature available on the subject. No serious research has been conducted in this direction so far. The purpose of this paper is to provide an overview of natural disaster scenario, to understand the historicity of disasters in Kashmir with their frequency, document the disaster mitigation mechanism in Jammu and Kashmir and to suggest measures for reducing vulnerability to hazards.

The data pertaining to the topic has been extracted and researched from primary and secondary sources. Primary sources include books, manuscripts, texts, agreement documents, etc. while as secondary sources include diaries, magazines, books, articles, reports that analyze events and people in order to put them into a historical context, newspapers, Interviews of subject experts, etc.

Strategically located Jammu And Kashmir State constitutes the northern most extremity of India. The entire State lies between 32.17" and 36.58" North altitude and East to West, the State lies between 73.26" and 80.30" longitude. There are many low lying valleys in the state like Tawi Valley, Chenab Valley, Poonch Valley, Sind Valley and Liddar Valley, but the main Valley is the valley of Kashmir, which is $100 \mathrm{kms}$. wide and 15520.3 sq. kms. in area. Through this valley flows the river Jhelum with its tributaries. The height of the valley above sea level is about 1700 meters. The total area of the state is 2, 22, $236 \mathrm{sq} \mathrm{kms}$ including $78114 \mathrm{sq}$ kms under the occupation of Pakistan and 37,555 sq kms under that of China. The state is bounded by Pakistan, 
Afghanistan, and China from the West to the East. (Raina, 2).

Kashmir, also called the Jhelum Valley is bounded on all sides by mountains. The river Jhelum, which flows out from the spring at Verinag in Anantnag district, passes through this Valley at a very slow speed and ultimately flows out through a narrow gorge at Baramulla. Districts of Srinagar, Ganderbal, Anantnag, Baramulla, Bandipora, Kupwara, Shopian, Budgam and Pulwama lie in this valley. Average height of the valley is 1850 meters above sea level but the surrounding mountains, which are always snow-clad, rise from three to four thousand meters above sea level. The surface of the valley is plain and abounds with springs, lakes and health resorts.(Raina, 4)

Mountains have a special geographical importance to the State of Jammu and Kashmir. Kashmir valley is enclosed by high mountain-chains on all sides except for certain passes and a narrow gorge at Baramulla. There are Siwalik hills towards the south and very lofty mountains in the north, the peaks of which always remain covered with snow. There are volcanic mountains too in the State. They have caused havoc in Kashmir in the past.

The climate varies from tropical in Jammu plains to semi-arctic cold in Ladakh with Kashmir and Jammu mountainous tracts having temperate climatic conditions. The annual rainfall also varies from region to region with $92.6 \mathrm{~mm}$ in Leh, $650.5 \mathrm{~mm}$ in Srinagar and $1115.9 \mathrm{~mm}$ in Jammu. A large part of the State forms part of the Himalayan Mountains. The State is geologically constituted of rocks varying from the oldest period of the earth's history to the youngest present day river and lake deposits.

\section{Disaster Scenario}

Owing to a unique geo political and geographical setting, the State of Jammu \& Kashmir has witnessed a multitude of disasters. Ranging from the local incidents of fires upto catastrophic earthquakes, the State has always paid heavily in terms of loss of life and property. However, in the absence of a reliable record and information, most of the events are either partially reported or exaggerated or sometimes not recorded at all. Below are documented main disasters that had occurred in the state in the past.

Earthquakes: - Geologically speaking Jammu and Kashmir is part of the young folded Himalayan Mountains which fall in geological history of mountain building movements in the country. Being located in mountain building zone, seismic activity of varying intensity is a recurrent phenomenon. Large number of earthquakes of a magnitude of 5.0 (Richter scale) has occurred within the State particularly the Kashmir Valley. Between 1889 to 1990 A. D. about 170 earthquakes have been listed indicating an average return period of about 8 months for one such earthquake'. The city of Srinagar, which forms the core of Kashmir valley, has suffered extensive damages by two earthquakes of magnitude 7.0 (Richter scale) and 6.5 in 1889 and was destroyed again in 1963 earthquake of magnitude of 5.3 (Richter scale). The Anantnag town has also been damaged by two earthquakes of 5.0 and 5.5 magnitude (Richter scale) in 1961. In the vulnerability Atlas of the country, whole Kashmir valley has been identified as seismic zone IV with an elliptical area covering Baramulla and Srinagar in Zone V of IS 1893-1984. These zones are referred to respectively as High Damage Risk Zone of MSK VIII and Very High Damage Risk Zone of MSK IX in the Vulnerability Atlas.

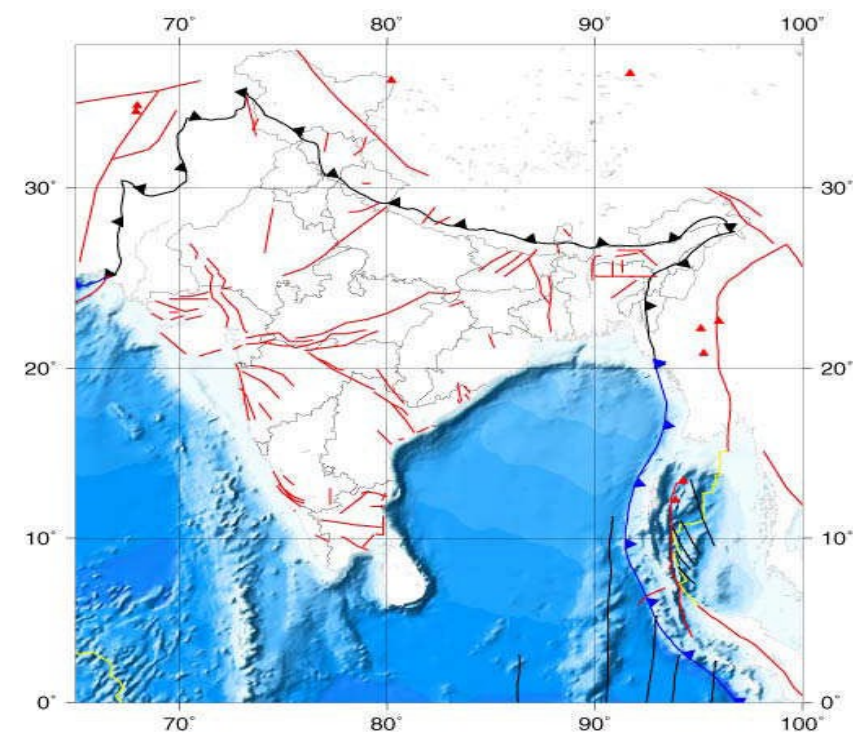

Tectonic Map of India. Red lines showing active fault zones

| (Source www.asc-india.org) 
Moderate earthquakes less damaging than the recent 2005 Kashmir event occurred in 1878 $\mathrm{M}=6.7$ Abbottabad, 1885 (Mw=6.3) near Srinagar, 1905 (Mw7.8 Kangra), in 1842 (Mw7.5 Kunnar), and in 1974 $(\mathrm{Mw}=6.2$ Pattan). In numerous popular accounts since the October earthquake a 1 Feb 1929 deep Mw7.1 Hindu Kush earthquake is erroneously stated to have occurred in northern Pakistan as a $\mathrm{Mw}=8$. The 1885 and 2005 Kashmir earthquakes were approximately contiguous and may have occurred on the same 37 degree NE dipping ramp. The 1905 Kangra earthquake, however, is believed to have ruptured part of the shallow-dipping Himalayan devolvement, typical of great Himalayan ruptures to the east. The 1555 Kashmir earthquake is estimated to have been $\mathrm{Mw}=7.6$ by Ambraseys and Douglas (2003) but may have been much larger.

\section{MAP OF INDIA SHOWING SEISIC ZONES OF INDIA As per IS 1893 part-I, 2002}

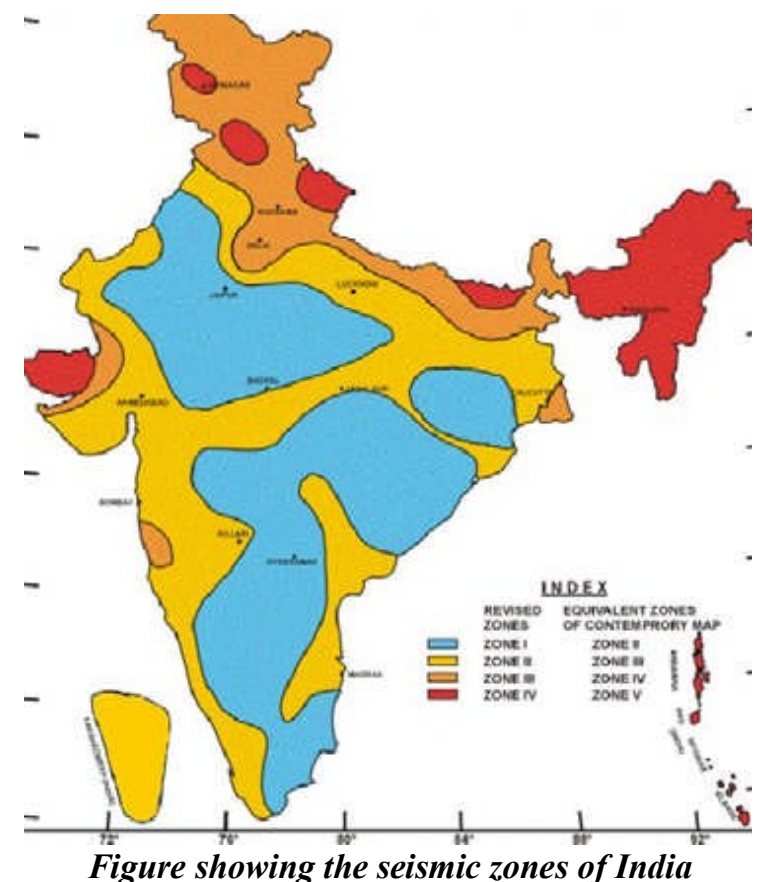

The Country is divided into four seismic zones - I, II, III \& IV

\begin{tabular}{|c|l|}
\hline Zone & \multicolumn{1}{|c|}{ Intensities of Earthquakes in each zone } \\
\hline II & $\begin{array}{l}\text { This zone is susceptible to earthquakes that can be felt by all and may frighten people enough to run outdoor. Dishes and } \\
\text { glassware break, books fall down, heavy furniture gets moved. Few instances of fallen plaster and some damage to } \\
\text { buildings may also be observed (Intensity: I to VI) }\end{array}$ \\
\hline III & $\begin{array}{l}\text { In Zone III, earthquakes of higher intensity may be felt. Earthquake that frightens everyone, making it difficult for people } \\
\text { to stand. Even people in moving vehicles may feel such quakes. Structures/buildings of good design and construction } \\
\text { suffer slight damage while poorly designed/build one suffer considerable damages (Intensity: VII) }\end{array}$ \\
\hline IV & $\begin{array}{l}\text { This zone is susceptible to strong earthquakes, which create panic all over, moving even heavy furniture. Such } \\
\text { earthquakes can create moderate damage in well designed/built structures/building, while poorly built structures suffer } \\
\text { great damages. Other effects could be landslides on steep slopes, crackes in ground up to widths of a few centimeters and } \\
\text { water in lakes could become turbid (Intensity: VIII) }\end{array}$ \\
\hline V & $\begin{array}{l}\text { This is the maximum risk zone in the country and is susceptible to great earthquakes. Quakes that can cause total panic } \\
\text { and considerable damage to life and property. Considerable damages happen even in spacey designed structures. Great } \\
\text { damage in buildings with partial or total collapse. Railway tracks bend and roadways get damaged. Ground cracks to } \\
\text { widths several centimeters. Underground pipes break, landslides, rock falls and mud falls occur, large waves in water } \\
\text { where intensities exceed XI, total destruction may be caused with changes in landscape that could even change the } \\
\text { courses of rivers. (Intensity: IX) }\end{array}$ \\
\hline
\end{tabular}

Districts of the state in Zone V:

Anantnag, Baramulla, Kathua, Kupwara, Pulwama, Srinagar, Kargil

Districts of the state in Zone IV:

Badgam, Doda, Jammu, Poonch, Rajouri, Udampur, Leh (Ladakh) 


\section{Earthquakes In Kashmir -}

Kashmir has a history of earthquakes. The only difference lies in the fact that Kashmir being hidden in the Himalayas and due to its continuous inaccessibility for months on and every year due to its weather and geographic location, did not attract much attention from the work in times of disasters.

A previous catastrophic earthquake in Kashmir occurred in 1555 but here is insufficient data to assign it a magnitude or location. Its severity suggests that it may have been larger than the recent earthquake. Five decades earlier a moderate $\mathrm{Mw} \approx 7.3$ earthquake damaged Kabul, and a great $600-\mathrm{km}$-lomg $8.2<\mathrm{Mw}<8.6$ rupture in the central Himalaya destroyed monasteries in Tibet and buildings in Agra.

The damaging Kashmir 1555 earthquake was preceded in 1501 by a damaging earthquake of unknown magnitude also in Kashmir. Also it is known that Himalayan earthquakes can trigger others. For example in 1833, two major earthquakes preceded the $\mathrm{Mw}=7.8$ main shock in Nepal by 5hours and 15 minutes respectively, alerting local residents and resulting in a very minor loss of life. The 1909 Afghan earthquake consisted of two events 1 minute apart, and the Kangra earthquake had a M7 earthquake in its coda some 7 minutes after the main shock.

\section{Significant Earthquakes in Jammu \& Kashmir}

The following list briefly outlines known earthquakes in this region. General locations are provided for historical events for which "generalized" epicentral co-ordinates are available.

6 June 1828 - Srinagar area (Jammu \& Kashmir),

Magnitude: 6.0 TS

Epicentre co-ordinates: $34.08 \mathrm{~N}, 74.833 \mathrm{E}$

This earthquake caused widespread devastation in Srinagar and other parts of the Kashmir Valley. 1,000 people were killed in this earthquake.

30 May 1885 - NW of Srinagar (Jammu \& Kashmir),

Magnitude: 7.0 TS

Epicentre co-ordinates: $34.60 \mathrm{~N}, 74.38 \mathrm{E}$

This earthquake is one of the deadliest shocks in Kashmir. It was centred just north of the Wular Lake. It jolted the Valley of Kashmir and along with it Srinagar, Baramulla and Sopur. 3,200 people are said to have been killed in this earthquake. There were also unconfirmed reports of fissures in the ground as a result of the quake. The Kamiari area was totally destroyed.

17 May 1917 - Ladakh (Jammu \& Kashmir)

Magnitude: $6.0 \mathrm{TS}$

Time: 21:45:50

Epicentre co-ordinates: $34.20 \mathrm{~N}, 77.50 \mathrm{E}$

11 November 1921 - Ladakh (Jammu \& Kashmir),

Magnitude: $\quad 6.0 \mathrm{TS}$

Time: 01:18:45

Epicentre co-ordinates: $34.20 \mathrm{~N}, 77.50 \mathrm{E}$

15 November 1937 - Northern Ladakh (Indo-China Border region)

Magnitude: $6.0 \mathrm{TS}$

Time: 21:37:22

Epicentre co-ordinates: $35.10 \mathrm{~N}, 78.10 \mathrm{E}$

22 June 1945 - Near Padua, Kathwa District, J\&K (H.P.-J\&K Border region)

Magnitude: $6.0 \mathrm{TS}$

Time: 18:00:51

Epicentre co-ordinates: $32.599 \mathrm{~N}, 75.90 \mathrm{E}$

10 July 1947 - Near Padua, Kathwad District, J\&K (H.P.-J\&K Border region)

Magnitude: $6.0 \mathrm{TS}$

Time: 10:19:20

Epicentre co-ordinates: $32.599 \mathrm{~N}, 75.90 \mathrm{E}$

12 August 1950 - Near Padua, Kathwad District, J\&K (H.P.-J\&K Border region)

Magnitude: $6.0 \mathrm{TS}$

Time: 03:59:06

Epicentre co-ordinates: $32.599 \mathrm{~N}, 75.90 \mathrm{E}$

12 August 1950 - Gilgit Wazarat (P.O.K.)

Magnitude: $6.0 \mathrm{TS}$

Time: 06:16:12

Epicentre co-ordinates: $36.20 \mathrm{~N}, 73.00 \mathrm{E}$

12 September 1951 - Chamba-Udhampur Districts (H.P.-J\&K Border region) 
Magnitude: $6.0 \mathrm{TS}$

Time: 20:41:48

Epicentre co-ordinates: $33.30 \mathrm{~N}, 76.50 \mathrm{E}$

17 June 1962 - Udhampur District (Jammu \& Kashmir)

Magnitude: $6.0 \mathrm{TS}$

Time: 04:39:26.6

Epicentre co-ordinates: $33.30 \mathrm{~N}, 76.20 \mathrm{E}$

22 June 1965 - Ladakh (Jammu \& Kashmir)

Magnitude: $6.1 \mathrm{TS}$

Time: 05:49:18.90

Epicentre co-ordinates: $36.30 \mathrm{~N}, 77.70 \mathrm{E}$

28 December 1974 - NE of Malakhand, NWFP, (Indo-Pakistan Border region)

Magnitude: 6.2 (NEIC)

Time: 12:11:43.70

Epicentre co-ordinates: $35.054 \mathrm{~N}, 72.870 \mathrm{E}, 22 \mathrm{kms}$ depth

28 April 1975 - Aksai Chin (Indo-China Border region),

Magnitude: $6.3 \mathrm{TS}$

Time: 11:06:43.50

Epicentre co-ordinates: $35.819 \mathrm{~N}, 79.915 \mathrm{E}, 33 \mathrm{kms}$ depth.

12 September 1981 - Gilgit Wazarat (P.O.K.),

Mw 6.1 (HRV), mb 6.2 (NEIC)

Time: 07:15:54.17

Epicentre co-ordinates: $35.693 \mathrm{~N}, 73.594 \mathrm{E}, 33 \mathrm{kms}$ depth

At least 220 people were killed, 2,500 were injured in the Gilgit region. There were also unconfirmed reports

of surface faulting. The shock was felt in Srinagar (J\&K, India) and in Peshawar and Rawalpindi (Pakistan).

6 July 1986 - Xizang (Indo-China Border region),

Ms 6.1 (NEIC)

Time: 19:24:22.99

Epicentre co-ordinates: $34.424 \mathrm{~N}, 80.161 \mathrm{E}, 9 \mathrm{kms}$ depth

5 March 1990 - Gilgit Wazarat (P.O.K.)

Ms 6.0 (NEIC)

Time: 20:47:00.76 UTC

Epicentre co-ordinates: $36.907 \mathrm{~N}, 73.021 \mathrm{E}, 12 \mathrm{kms}$ depth

25 March 1990 - Gilgit Wazarat (P.O.K.)

Ms 6.3 (NEIC)

Time: 14:17:18.82 UTC

Epicentre co-ordinates: $37.034 \mathrm{~N}, 72.942 \mathrm{E}, 33 \mathrm{kms}$ depth

19 November 1996 - Aksai Chin (Indo-China Border region),

Mw 6.9 (GS)

Time: 10:44:46.06 UTC

Epicentre co-ordinates: $35.345 \mathrm{~N}, 78.133 \mathrm{E}, 33 \mathrm{kms}$ depth

Felt in Hotan, Shule, Wushi and Yecheng (Xizang), China

28 January 2002 - Kithar, Jammu \& Kashmir

Mw: 5.3

Epicentre co-ordinates: 33.100 N, 75.987 E, D=30.8 kms,

Time: 22:33:42 UTC

A moderate earthquake struck southern Jammu \& Kashmir and adjoining parts of Himachal Pradesh, on 28 January 2002 at 04:03 AM local time. It had a magnitude of $\mathrm{Mw}=5.3$ and was felt strongly in parts of the region.

1 November 2002 - Astore Valley, P.O.K

Mw: 5.3

Epicentre co-ordinates: $35.361 \mathrm{~N}, 74.718 \mathrm{E}, \mathrm{D}=29.3 \mathrm{kms}$,

Time: 22:09:28 UTC

A moderate earthquake struck the Astore Valley in the Kashmir Himalayas, on 2 November 2002 at 03:39 AM local time that killed 1 person. It had a magnitude of $\mathrm{Mw}=5.3$. This earthquake was followed by additional moderate events on November 3rd and 21 st that resulted in further damage and casualties.

3 November 2002 - Astore Valley, P.O.K., Mw 5.3

Epicentre co-ordinates: $35.359 \mathrm{~N}, 74.636 \mathrm{E}, \mathrm{D}=15.1 \mathrm{kms}$,

Time: 07:33:35 UTC 
A moderate earthquake struck the Astore Valley in the Kashmir Himalayas, on 3 November 2002 at 12:33 PM local time killing 17 people and causing damage to property. It had a magnitude of $\mathrm{Mw}=5.3$. This earthquake followed a similar sized earthquake on 2 November and was followed by a larger event on 21 November 2002.

20 November $\mathbf{2 0 0 2}$ - $\quad$ Astore Valley, $\quad$ P.O.K., $\quad$ Mw 6.3 Epicentre co-ordinates: $35.345 \mathrm{~N}, 74.592 \mathrm{E}, \mathrm{D}=13.0 \mathrm{kms}$, Time: 21:32:27 UTC

A strong earthquake struck the Astore Valley in the Kashmir Himalayas, on 21 November 2002 at 03:02 AM local time killing 23 people and causing damage to property. It had a magnitude of $\mathrm{Mw}=6.3$. 8 October 2005 - Kashmir-Kohistan, Pakistan-India border, Mw 7.6 Epicentre co-ordinates: $34.432 \mathrm{~N}, 73.537 \mathrm{E}, \mathrm{D}=020.0 \mathrm{kms}$

Time: OT $=03: 50: 40$ UTC

A major earthquake struck the India-Pakistan border on the morning of 8 October 2005. It had a magnitude of $\mathrm{Mw}=7.6$ and was felt strongly in much of Pakistan, northern India and eastern Afghanistan. The earthquake resulted in more than 80,000 deaths in northern Pakistan and adjoining parts of Jammu \& Kashmir, India and is by far one of the deadliest in the sub-continent. At least 10 people also died in other parts of north India and 4 in Afghanistan due to this earthquake. Tremors from the earthquake were felt more than a thousand kilometres away in the Indian states of Gujarat, Madhya Pradesh and Uttar Pradesh.
23
October
2005
Kashmir-Kohistan
aftershock,
$\mathrm{Mw}$

Epicentre co-ordinates: $34.884 \mathrm{~N}, 73.024 \mathrm{E}, \mathrm{D}=10.0 \mathrm{kms}$,

Time: 04:16:48 UTC

A moderate aftershock struck the Kashmir Himalayas on 23 October 2005 at 15:04 UTC.

It was felt strongly in Kashmir \& the NWFP, causing additional damage to buildings weakened in the 8 October 2005 earthquake. It had a magnitude of $\mathrm{Mw}=5.3$.

This presents a clear picture of the fact that the state is highly vulnerable to earthquakes that has casused huge damages to the human as well as economic resources of the state.

\section{Floods:}

Major natural drainage system in the State includes the Indus, Jhelum and the Chenab flowing in three parts of the state. Out of the three systems, Jhelum River and its tributaries are more vulnerable to flooding. Ladakh is practically free from floods apart from occasional inundation due to 32000 hectares are protectable. In Kashmir valley flood is a recurrent problem occurring due to overflowing of embankments and breaching of river channels, horizontal erosion of river basin of Jhelum and flash flood in its tributaries of Doodh Ganga, Romushi, Rambiara, Udder, Madhumati, Pohru and Sukhnag etc. The hazard vulnerability from Anantnag to Srinagar city (including major settlement of Bijbehara, Awantipora, Anantnag and Srinagar etc) is due to insufficient carrying capacity of the river vis-a-vis very high discharge during floods. Ahead of Sopore, the outfall at Wular Lake, the problem is the insufficient capacity of outfall channel to quickly drain off the flood waters, heading up and inundating the shores of the Wular Lake and also results into back flood of water inundating Srinagar city and other intervening areas. The encroachment of river water channels and siltation in water bodies due to erosion has further aggravated the vulnerability of flood hazard in the valley. In Jammu region flood hazard is mainly due to spilling of banks and embankment erosion by river Chenab and river Ravi. The districts which are highly vulnerable to floods recurrently are Anantnag, Srinagar, Pulwama and Baramulla and districts moderately vulnerable are Jammu, Kupwara, Udhampur, Doda, Leh, Badgam, Poonch, Rajouri and Kathua.

"It has been estimated that about 7,000 houses are damaged due to floods annually in the State. The maximum of 98,000 houses was reported in floods in 1988" (Wani, 2002). Although flood hazard in the State is not frequent as is the case with major flood prone states in the Country but well planned Action Plan is a dire need to reduce the flood hazard vulnerability during heavy rains in the catchments of the rivers especially Jhelum. Management of flood plains of the flood prone areas is equally required to reduce damages to life and property.

\section{Flash Floods And Cloud Burst:}

Flash floods, short lived extreme events, which usually occur under slowly moving or stationary thunderstorms, lasting less than 24 hours are a common disaster in the state. As a result of the high velocity of the current which can wash away all obstacles in its way, this phenomenon has resulted in enormous loss of life and property in various parts of the region.

Glacial melting due to Global warming is another major cause of flash floods. The major glaciers in the higher mountains are receding at an alarming rate. Glaciers in Jammu and Kashmir are receding at a faster rate compared to other glacial regions in the world. In Suru basin alone, we have lost about $16 \%$ of glaciers in the 
last 40 years. Similarly, we have lost $18 \%$ of the Kolhai glacier, the main source of drinking water and irrigation in the valley, during the same period. Climate change is likely to affect a number of sectors, particularly irrigated agriculture, and horticulture and hydropower capacity in the state. Changes in flow magnitudes are likely to raise tensions between India and Pakistan, in particular with regard to reduced water flows in the dry season and higher flows during the wet season. Both parts of Kashmir face the risk of higher frequency of floods and increased threat to hydropower development.

Recently, Kashmir has been witnessing drastic decrease in the snowfall. This reduction in snowfall together with the fast receding glaciers has resulted in water scarcity for irrigation and hydropower generation in some seasons. The data shows that the magnitude and frequency of flooding has increased in the valley during the last few decades. Coupled with the unplanned urbanization and mismanagement of the Jhelum floodplains, the situation is going to be alarming in near future. One can well imagine the future scenario, with most of the wetlands that used to act as sponge during flooding, being urbanized and converted into concrete landscape.

Over 300 people were killed and property worth crores was damaged in the recent flash floods and cloudbursts in Jammu and Kashmir. As many as 234 people died in Leh and 424 were seriously injured, Rajouri district in Jammu division witnessed 20 deaths followed by Reasi (11), Anantnag (10), Kathua and Poonch (7 each), Doda and Baramulla (5 each), Jammu, Udhampur and Kargil (2 each) and Budgam and Shopian (one each). Baramulla suffered a loss of Rs 61 crore in agricultural sector and Rs 58.22 crore in the horticulture sector, the highest economic loss in the state. Shopian suffered a loss of Rs 10.35 crore in the horticulture sector. In the border district of Kupwara, damage caused due to floods is estimated by the government to be around Rs 75.40 crore.

Recent flash flood in Leh, Jammu and Kashmir - In the midnight of August 6, 2010, Leh in Ladakh region of $\mathrm{J} \& \mathrm{~K}$ received a heavy downpour followed by sudden cloud burst. Within a short span of about 2 hours, it recorded a rainfall of 14 inches. There were flash floods, and the Indus River and its tributaries and waterways were overflowing. As many as 234 people were killed, 800 were injured, and many went missing, perhaps washed away with the gorging rivers and waterways. There was vast destruction all around. Over 1000 houses collapsed. Men, women, and children were buried under the debris. Almost half of the people who died were local residents $(49.6 \%)$ and foreigners $(10.2 \%)$. Age-wise analysis of the deaths shows that the majority of deaths were reported in the age group of $25-50$ years, accounting for $44.4 \%$ of deaths, followed by the 11-25year age group with $22.2 \%$ deaths. The gender analysis showed that $61.5 \%$ were males and $38.5 \%$ were females. A further analysis showed that more females died in the age groups $<10$ years and $\geq 50$ years. (Gupta, 2012).

\section{Windstorms:}

Jammu and Kashmir falls in sub-Mediterranean climate zone with hot summers and cold winters. However, large variations are found in climate at micro level in its three distinctive regions. The cold desertic conditions of Ladakh are more prone to wind hazard and wind speed in Ladakh region is a high as $198 \mathrm{Km} / \mathrm{hour}$ which is comparable with "hurricane velocities" in the East Coast of India. In case of rest of the State, average design wind speed is $140 \mathrm{Km} /$ hour. Such wind speed could only occasionally be reached in what is called "Andhi". Occasionally Kashmir valley observes high-speed winds in summer due to high temperature, interspersed water bodies and thick forests, which act as microclimate factors responsible for high velocity local winds. In such events, weakly constructed structures of thatch, sheets etc. those with sloping roofs such as using thatch, AC. sheets and corrugated Galvanized Iron Sheet roofs which are not fully anchored and integrated, suffer damages due to wind. The damages occurring in "Andhis" is predominantly felt in the Kashmir Valley, damaging property and fruits especially in early spring season. It is mostly localized phenomenon and does not result in a disaster to the state as a whole. However, it would be beneficial and useful to adopt the wind resistant construction guidelines and implement them for minimizing wind damages.

\section{Landslides / Avalanches:}

The Himalayas are well known for the occurrence of snow avalanches particularly Western Himalayas i. e. the snowy regions of Jammu and Kashmir, Himachal Pradesh and Western Uttar Pradesh. In Jammu and Kashmir higher reaches of Kashmir and Gurez valleys, Kargil and Ladakh and some of the major roads are highly vulnerable. Being situated among the young folded mountains and hills, the State suffers extensively during rains and high intensity earthquakes. The mountains in Ladakh are barren with withered exposed bedrock which is very sensitive to wind erosion. The vulnerability of young folded mountains which does not have stable rock soil strata it is very serious which has further aggravated due to increased deforestation, construction of roads, terracing and change in agricultural practices and crop pattern. The snow avalanches and landslides during the winter of 1995 on both the sides of Jawahar Tunnel of Srinagar Jammu National Highway will be remembered for ever in which more than 150 precious lives were lost. The devastating landslides/avalanches in Jammu and Kashmir need in-depth research and studies for adopting more scientific and safe engineering methods to lessen the intensity of hazard and mitigate the problem. In the first stage, it would be imperative to 
identify the vulnerable areas through geological and geo technical studies. The landslide or avalanche prone areas shall have to be prohibited for development of settlements and buildings and those which have already come up shall have to be rehabilitated or protective measures shall have to be undertaken based on expert advice.

Fires - The state being located in hilly areas, thick vegetation cover on most of the mountains is subject to fires destroying rich forest wealth, fauna, flora and precious animal habitats. These fires are mostly taking place due to ill practices of the local people e.g. burning of bushes for making coal for Kangri on the one hand and negligence of the forest staff on the other. Such disasters have been witnessed even in Dachigam Rakh which shelters variety of animals and forest wealth including the world famous Hangul (a specie of stag). Such incidence needs to be checked and vulnerable areas need to be protected by providing training to forest staff to prevent and control forest fires.

Drought - J\&K State once a water surplus state now faces recurring droughts in all its parts. The state Govt. has to meet tremendous demands for food in the drought hit areas. The Food Security as thus remains the topmost priority with the Govt. There is hardly any district in the state, which does not face droughts occasionally. Apart from some man-induced contributors, the change in world climate seems to have contributed its impact here as well.

In addition to this large-scale deforestation, over exploitation of natural resources, rapid urbanizations, population explosion etc. are some of the key factors to intensify the impact of disasters. The state of Jammu and Kashmir as thus is one of the most vulnerable places to disasters.

\section{Disaster Management Mechanism}

The state of Jammu and Kashmir has the Department of Revenue as the nodal agency to deal with natural disasters. However, the Revenue Department is confined to assessment and distribution of relief materials both in kind and cash. The Financial Commissioner (Revenue) is the Relief Commissioner of the State. However, due to large-scale migration of some sections from the valley and some border districts to Jammu the Government has designated an officer as Relief Commissioner (Migrants) who has the overall charge of the migrant relief. The Divisional level Relief is the responsibility of the concerned Divisional Commissioner. At the District level the District Collector is the responsible authority to carry out relief operations in the shortest possible time. At the sub-district i.e. Tehsil level it is the Tehsildar who administers and supervises the relief operations while as at the village level it is the Patwari (the basic grass root level official in the Relief / Revenue hierarchy) who submits the damage assessment to the higher authorities.

However, from the point of view of the mitigation of natural disasters, as said above, there is hardly any long term strategy or policy with the Govt. The concerned state Departments like Irrigation and Flood Control, Police, Relief, Transport, Health, PDS (Public Distribution System) and Consumer Affairs etc. are always seen involved with short term or reactive measures especially relief distribution and other rehabilitation works instead of any long term preparedness and mitigation strategy. The District Control Rooms are set up whenever there are excessive rains and chances of floods but vis-a-vis other calamities hardly any thing has been done. As such there is dire need to have a State Disaster Management Plan for which some initiatives have hopefully been taken. However the following suggestions deserve attention, particularly of those who are at the decision making level.

The legislative framework that exists in respect of urban planning and/or development in the state includes State Building Act (1920 AD), Land Acquisition Act (1934 AD), Land Revenue act (1939 AD), J\&K Municipal Act (1951 AD), J \& K Town Area Act (1954 AD), J \& K Land Grants Act (1960AD), Natural Calamities Destroyed Areas Improvement Act Premises Eviction Act, Ribbon Development Act, Town Planning Act (1963 AD), J \& K Development Act (1970), Land Improvement Schemes Act (1972 AD), J\& K Housing Board Act (1975 AD), J \& K Building Operations Act (1988 AD) and Municipal Corporation Act (2000 AD).

From this it is clear that the building regulations have even started from Maharaja's period and it is noteworthy that the above said legislations have come into force at different times, in different conditions and for different objectives \& purposes but in none of the Acts there has been any regulation/byelaws for any natural disaster including earthquakes except Natural calamities Destroyed Improvement Act where in some sort of rehabilitation measure was taken care of.

The first Master Plan (1971-91) of Srinagar City is non-descriptive about earthquake sensitivity except showing a figure indicating the areas under Kashmir valley earthquake of 1885 and 1963 and a two line statement mentioning that seismic zones lying towards south west of Local area on Budgam and its adjacent areas limit the height of our buildings and lateral expansion of the city towards that side. Same negligence has been repeated in toto in the present Master plan (2001-2021). No further description or guidelines have been proposed after 30 years of the first Master Plan was formulated. 
There have not been any studies with regard to identification of flood prone / landslide areas of Srinagar city. Further there is no data available regarding snow loads at different places of the valley. Apart from this, there are no studies with respect to wind forces and no data available for avalanche sites. Same stands true for earthquake vulnerability as different places in Kashmir will behave differently during this unpredictable disaster. The general nature of soil types has been described in the State Gazetteer but detailed studies are required to be made in terms of behaviour of these soils.

Similarly old vernacular architecture particularly Dajji Dewari (Brick knogging technique) is not documented properly and there are no studies in the wooden architecture of the valley. The Dajji Dewari technique is quite feasible for earthquake resistance and therefore requires in depth study. Quite a good number of houses in the old city have used this technique. There are also no factual studies available in spatial development at city level. Further in terms of earthquake resistance, there is no data available as to how many buildings are safe but it is likely that only small percentage of less than $15 \%$ of total stock may be on safer side in city. The reason being that the transition in terms of technique of construction was not structurally sound. The major chunk of building and houses although in pacca construction but lacks the technical feasibility in terms of .earthquakes. Only R.C.C framed structures which are being built in Government controlled constructions and also private-public buildings (except detached/semi detached houses of 2 to 3 storey) seem to be feasible under minimum resistance. Also no studies are available in terms of the quantum of open spaces in cities, which would actually act as secure/relief zones during earthquakes

The Municipal Corporation has a major role in terms of increasing the status of earthquake resistance of built environment. This agency is basically responsible for rejecting a building proposal or permitting it. Majority of the sanctioned permissions are violated by the intending owners/developers. Whatever information regarding building permission/rejection is heaped up in the shelves of SMC is totally different from whatever stands on ground. The quality of drawings including the technical, as well as design information provided in the sanctioned maps is far from reality in overall sense.

\section{Disaster Mitigation}

The occurrence of natural disaster can't be stopped but their impact can be reduced. For this purpose there is need to co-operate with each other at all the possible levels, i.e. sharing of expertise in the respective field, monitoring and sharing of the scientific data related to hazards, co-operation in issuance of warnings about floods, avalanches, landslides, dam breaches etc. As far as earthquakes are concerned all the Himalayan countries are equally likely placed with respect to this disaster. Unfortunately we do not have any authentic and systematic past records of seismic activities in entire Himalayan belt except a few fragmentary records of recent past.

Except adhoc measures taken from time to time by the Government to mitigate the after-effects of the hazards no concrete steps have been taken to tackle the crisis / situation in case of the natural hazards. Keeping in view the Bhuj (Gujarat) earthquake of 26th January, 2001 and October 8, 2005 Kashmir Earthquake, it becomes imperative for the Government authorities concerned to take appropriate measures for disaster reduction involving preparedness, prevention and mitigation measures. In addition, strategic policies need to be framed to provide technical guidelines and action plans to mitigate disasters in the vulnerable areas.

The earthquakes which have occurred in the valley have been recorded in the annuals of the history and traditionally the people of the state in general and Kashmir in particular by experience had resorted to various conventional constructional technologies. "Dhaji Diwari", an indigenous construction method was developed which helped the people to reduce the effect of earthquake disaster. In such structures timber beams are used to reduce the effect of earthquake disaster. In such structures timber beams are used as runners at various levels in sun-dried bricks and burnt bricks of various sizes or stonewalls going across the corners and junctions of the walls. The past experience and observation reveals that the structures constructed by using such indigenous technologies are more stable and earthquake resistant in seismic intensities up to MSK VIII. Over last few decades, especially since early eighties, the construction technologies and practices in the Valley have undergone several changes due to modernization, high cost or non-availability of timber change in the aspirations and tastes of the people and so on. The timber beams have been replaced by cement concrete, sun dried bricks by stones and mechanized bricks, wooden roofing by cement slabs without any consideration to climate, stability of soil and consideration of vulnerability to earthquakes. It is, therefore, imperative to make people aware about adoption of safer modern construction technology to avoid any mega disaster. Therefore, immediate measures are warranted in Valley (High Seismic Risk Zone) in adoption of new construction and seismic retrofitting of existing unsafe buildings as preventive measures.

Due to the fact that Srinagar City has been categorized as highest risk zone (Zone V), therefore without wasting further time, it is recommended that concrete steps need to be taken on priority and the whole Kashmir valley/region be planned on Zone $\mathrm{V}$ factor. 


\section{Legislative Framework:}

1. Taking advantage of the existing Acts, some amendments particularly inclusion of steps for earthquake resistance of buildings in the form of rules/regulations are required under Building Operation and Control Act (BOCA), Development Act, Municipal Corporation Act or Town Planning Act. This shall be a time saver till a final draft Model is prepared for the whole Kashmir region.

2. There is a need to amend Development Act 1970, and earthquake resistance policies/guidelines need to be introduced through rules/regulations so that Town Planning Schemes or Zonal Development Plans or Area Dev. Plans under this Act are fruitful.

3. Architects need to be provided lead role in preparation of proposals of Building Permissions under BOCA which must bear a certificate from Structural Engineer regarding Safety factor. This requirement is of paramount importance and need to be introduced through rules/regulation in Municipal Corporation Act (2000 AD) and Building Operation \& Control act (1988 AD) at the earliest.

Progress certificate, Completion certificate, Occupancy certificate and final executed/built-up drawings from architects need to be placed on record in Corporation or Authority and this provision be included as part of rules/regulations of all these above mentioned Acts. This shall remove the ambiguity in terms of records and ground reality.

4. The third Master Plan (2021-2040) of Srinagar city has to be purely planned on the concept of reducing the risk of disasters apart from other aspects of city planning. Three types of planning norms with respect to plain areas, karewas and mountains slopes including top of mountains/hills can be put in detail. The proposed Developed area needs to be safe from all hazards particularly earthquakes, landslides, floods and high winds/snow storms.

There is a need to amend these urban development acts in a comprehensive manner. Today we might amend the act as per disaster mitigation but tomorrow, there could be a thrust on heritage concerns and later on there shall be thrust on environmental degradation, Therefore let the govt. or concerned agencies formulate integrated acts so that disaster mitigation, sustainable development, heritage conservation and barrier free built environment are essential parts of the amended acts, It takes years to amend an act and why should, we do it in piece meals, While changing the present status of the acts, we must look 100 years beyond from today.

\section{Awareness campaign}

Only Byelaws/Rules and Regulation will not help to overcome the problem, unless there is a sustained awareness among citizens and different sections of the society. Two drills (one in summer and one in winter) must be conducted for the city as a whole. These two dates must match with the dates of separate categories listed below. Following guidelines shall give an idea of what to do in this direction.

(i) Print and electronic media must carry the message of earthquake preparedness after regular intervals of time gaps.

(ii) The concerned writers must keep on informing the citizens of happenings around the world in seismic aspect.

(iii) All Educational institutions (including Women's Colleges/University) in the city must conduct regular drills at least once in a month. This must be compulsory. Hostels should do the same twice in a year.

(iv) All Hospitals must conduct drills at least on quarterly basis.

(v) All Hotels must conduct drills at least twice during peak tourist season.

(vi) All Industrial estates/areas must also conduct drills at least thrice a year.

(vii) All residential areas/ commercial areas must conduct drills twice in it year.

(viii) Volunteers from educational institutions particulars colleges, who are trained in civil defence can act as good human resource during disasters. All Degree Colleges should train min. 50 students annually for this purpose. This is excluding NCC/NSS cadets.

(ix) All cadets of NSS/NCC from Colleges must be compulsorily trained in disaster Issues.

(x) Special training for Medical Staff, Fire Service personnel, Municipal Staff, Water Supply/ Drainage and Electric Staff in their respective fields, Even road construction staff require training for disaster mitigation. Further personnel from communication services like telephones (landline/mobile) do need to be provided tips: for service management. 


\section{References}

[1]. Raina, A.N. Geography of Jammu \& Kashmir State. Jammu, Radha Krishan Anand \& Co (2002)

[2]. Jammu \& Kashmir - Geography \& Geology [as retrieved from http://www.peacekashmir.org/jammu-kashmir/geography.htm on April 16, 2014]

[3]. Draft J\&K State Disaster Management Policy published by Governement of Jammu and Kashmir (2013).

[4]. Gupta, Preeti, Khanna, Anurag \& Majumdar, S. Disaster Management in Flash Floods in Leh (Ladakh): A Case Study. Chandigarh (India), Indian Journal of Community Medicine (Official Publication of Indian Association of Preventive and Social Medicines) (2012).

[5]. Dar, G.M. Disaster Management - present status and future strategies, with special reference to J\&K. Indian Institute of Management, Public Administration \& Rural Development, J\&K (2008)

[6]. Rajeshwar, V., Sud, S.C. \& Gupta, S.C. Flood Forecasting in Jhelum Basin

[7]. Raza M, Ajaz-ud-din \& Mohammad, A. Kashmir Valley, Vol. II. New Delhi, Vikas Publishing House

[8]. The Daily Alsafa, Srg. $16^{\text {th }}$ September, 2003

[9]. The Daily Greater Kashmir, June 30, 2007

[10]. Vulnerability Hazard Atlas of India, (1999) BMPTC, New Delhi.

[11]. Damage and Need Assessment Report of J\&K Earthquake University of Kashmir and TISS (2006)

[12]. Lawrence, Walter R. Valley of Kashmir. London, London H. Frowde (1895)

[13]. Hussian, Majid. Geography of Jammu and Kashmir. J\&K (India) 